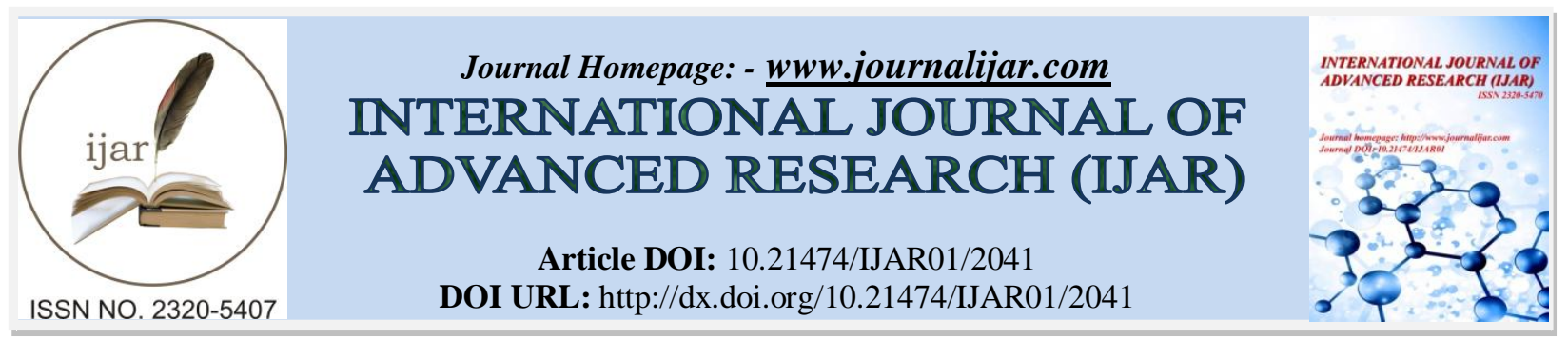

RESEARCH ARTICLE

\title{
THE DETERMINANTS OF EMPLOYEE PERFORMANCE: ROLE OF HUMAN CAPITAL DEVELOPMENT PROCESS
}

Tri Prihatini.

Faculty Member of Perbanas Institute.

\section{Manuscript Info}

Manuscript History

Received: 29 September 2016

Final Accepted: 15 October 2016

Published: October 2016

Key words:-

employee performance, human capital.

\section{Abstract}

Employee performance in the research place tended fluctuated form time to time. Some previous Researches informed that problem on employee 'performance can be the caused by some factors. Although the company has a standard operating procedure as a guide, employee performance is still not good enough to fulfill a market need. So, aim of this research is to know and analyze the determinants of employee performance based on human capital process. Through quantitative analyzes with population is all the employees in the third biggest company, and using principal component analysis, this research conclude that the form 40 dimensions, there are 10 dimensions as dominant factors. The three most dominant factors are people development, leadership, and outsourcing's employee. This research suggests that the firm should develop their employee, including outsourcing, systematically based on their fields. It is also that leadership is an important factor to maintain employee professionally through bottom up decision making. So that, firm culture and fairness of management can encourage employee performance.

Copy Right, IJAR, 2016,. All rights reserved.

\section{Introduction:-}

In facing a competition, it is needed to develop business management system in older to make effective and efficient for the company. This means that the need for change and capability to adjust and accept any changes makes the company can achieve its goals. Recently, world economic growth tends to decrease slowly and effect on the company's performance. A number of companies, then, take action to reduce inefficiency in all aspects of corporate performance. So that the company can survive and strive in order to the company keep growing. The companies can succeed and grow not only determined by the success of financial management but also success in managing the company's performance.

Employee performance is the result of company activities (Bernardin and Russel, 1993, in Ahmad S. Ruby and Tika, 2014). Further, they said that there are a number of factors that influence performance. The phenomenon that appears in place of research is the performance decline from no. 1 producer of roofing and cladding in Indonesia, and today is ranked no. 3 in terms of production volume. Initial studies show that standard Operating Procedure (SOP) has been standardized and implemented since 1992, and it has been classified in their respective job description in detail in each department. Furthermore, goals and targets for each division have been planned or agreed upon and recorded at each end of the year. 
Key Performance Indicator (KPI) has been imposed under the SOP, Job description, KPIs and targets have been prepared. Head of the company has been monitoring appear periodically. Thus the leadership to make sure that the management function which POAC (Planning, Organizing, Actuating and Controlling) can be run in accordance with the agreement between management and employees.

Robbins and Coulter (1999) said that there are three steps in the organization of an open system. There are input, process and output. In the input process, it consists of raw materials, human resources, capital, and information. In the process there are activities of employees, management and technology activities and their methods of operation. In the output process consists of existing products and services, financial results, information and human results. Especially for the design of human capital in three steps are then divided into three stages, namely strategic planning, human capital, and human capital acquisition information system (Sunarwa, 2011). Each stage has a dimension and measurability of performance indicators to employees. This study analyzes the dominant factor employee performance based design concept, the process of human capital.

\section{Theoretical Framework:-}

Thomas, Cheese and Benton (2003) believe that people are the most important assets. Many executives do not aware that investment in people leads to improved business results. Development of human capital in an organization is a crucial thing to improve employee performance. In addition, Subanidja and Rajasa (2016) stated that human capital, knowledge management, and other factors related to the company's performance.

Employee performance is the totality of the work that has been achieved by an organization Nawawi (2013). Moreover, employee performance according to Simanjuntak (2005), is a level of achievement of results on the implementation of certain tasks given and can be resolved. Suwarto (2014) informed that employee performance as an attitude or behavior which is produced by the workers. This is not about what is produced or the impact of employee performance. There are two behavioral characteristics that can be categorized within the employee's performance. The first is an evaluative employee performance, which can be interpreted evaluative employee performance can be rated negative, neutral, or positive for the effectiveness of the individual or company organsisasi. It is intended to find out the results of the value of the person's behavior whether it contributes to the achievement of objectives in the organization of the company. Both, employee performance multidimensional, which means there are several different kinds of behavior that has the ability to be able to promote or inhibit the company's goals.

According to Suntoro, 1999 (in Tika 2014), the employee's performance is the result of work achieved person or group of people from an organization to achieve organizational goals within a specific time period. According to Tika (2014), the elements of the performance of the organization's employees the company consists of: results of job functions, factors that affect the achievement of workers, achieving organizational objectives and in specific time period.

An explanation of the results of the elements of the performance of the company's employees can be defined that employee performance is a job function or activity of a person or group of organizations is influenced by various factors to achieve organizational goals of drawing a specific time period. It serves job or activity intended is the implementation of the work or activities of the organization group under the authority and responsibility within a particular organization.

According to Tika (2014) job functions / activities related to the performance of the company's employees are: the first is the strategy of the Company. The company's strategy has related with the company's mission, where business strategies required for achieving the objectives of a company and the business environment. According to Husein Umar (2010), the components that are used to analyze the company's strategy consist of business strength and dimensional dimensions attractiveness of the company. Dimensions of the power business consists of product prices, the number of outlets, turnover per month, potential sales and number of visitors per month in place of sales.

According to Umar (2010), the resources need a training to prepare workers in the running of company future. Training and development programs aimed at covering the gap between the skills of workers and office demand in addition to improving efficiency and effectiveness in achieving work targets. According to J.D. Martin et al (1995) (in Tika 2014) the company's goal is to maximize profits or wealth, especially for its shareholders. It may be obtained from the increase and maximize the market value of the stock price of company. Furthermore, evaluation 
of business financial aspect is performed to determine whether the realization of the investment has been as expected or not. By analyzing the profit by comparing expenditure and income, the availability of funds, cost of capital, the project's ability to make debt payments and to assess whether the project can be developed sustainably.

Sunarwa (2011) elaborated the human capital into the strategic planning process, human capital acquisition, human capital development, human capital engagement, human capital reward. In addition, David P Lepak and Scott a. Snell (1999), mentioned that employee performance has a relation with human resource architecture. Whereas, Marimuthu, Arokiasamy, and Ismail (2009) stated that human capital development has an impact on firm performance. However, there is no research so far, that there is no result what is the dominant factors as dominant factors impacting on employee performance.

\section{Methods:-}

The population in this study is all roofing and cladding company employees in the third largest company in Indonesia. There are 110 employees consisting of permanent employees and contract employees, and employee outsourcing. Leaders of companies are not included in the definition of employees Number of 110 respondents were active employees who do not leave based on data from Human Resources Department. Number of sample in this study is 110 respondents.

In collecting data, it uses questionnaire. In this study, it is used factor analysis. The factor analysis is used to summarize some of the information the resulting from the measurement process (in the form of concepts) into a number of smaller dimensions or construct hereinafter called factor (Subanidja, 2015). This research uses Test of Kaiser-Meyer- Olkin (KMO) Measure of Sampling Adequacy (MSA). Level of measurement is used value of KMO MSA that is greater than 0.5. Method used in this research is principal component analysis.

\section{Results and Discussion:-}

The final result of factor analysis can be presented as follows. Table 1 shows that number of KMO and Bartlett's test was 0.914, with a significant number of 0:00. Therefore number KMO and Bartlett's test is above the value of 0.5, and significant number is far below the value of 0:05.

Table 1:- KMO and Bartlett's Test

\begin{tabular}{|l|l|r|}
\hline Kaiser-Meyer-Olkin Measure of Sampling Adequacy. & .914 \\
\hline \multirow{3}{*}{ Bartlett's Test of Sphericity } & Approx. Chi-Square & 369.875 \\
\cline { 2 - 3 } & df & 45 \\
\cline { 2 - 3 } & Sig. & .000 \\
\hline
\end{tabular}

Table 2 shows the total variance explained. In this table, the value of the initial Eigenvalues is $47078 \%$. This value is analyzed from the 40 dimensions that may explain the relative importance on the development of human capital. The dominant factor explains $47.078 \%$ of all dimensions. The remaining amount of 52.922 is explained by other factors outside the dominant factor.

Table 2:- Total Variance Explained.

\begin{tabular}{|c|c|c|c|c|c|c|}
\hline \multirow[t]{2}{*}{ Component } & \multicolumn{3}{|c|}{ Initial Eigenvalues } & \multicolumn{3}{|c|}{ Extraction Sums of Squared Loadings } \\
\hline & Total & $\begin{array}{c}\% \text { of } \\
\text { Variance }\end{array}$ & Cumulative $\%$ & Total & $\begin{array}{c}\% \text { of } \\
\text { Variance }\end{array}$ & Cumulative $\%$ \\
\hline 1 & 4.708 & 47.078 & 47.078 & 4.708 & 47.078 & 47.078 \\
\hline 2 & .907 & 9.066 & 56.145 & & & \\
\hline 3 & .703 & 7.035 & 63.180 & & & \\
\hline 4 & .654 & 6.537 & 69.717 & & & \\
\hline 5 & .629 & 6.287 & 76.004 & & & \\
\hline 6 & .556 & 5.563 & 81.566 & & & \\
\hline 7 & .547 & 5.470 & 87.036 & & & \\
\hline 8 & .523 & 5.232 & 92.268 & & & \\
\hline 9 & .391 & 3.905 & 96.173 & & & \\
\hline 10 & .383 & 3.827 & 100.000 & & & \\
\hline
\end{tabular}


Picture 1 shows, that the scree plot illustrates the dominant factor of human capital development in the research process. The figure shows that the eigenvalues tend to decrease sharply. However, the next numbers of eigenvalues tend to decrease gradually. Thus the dominant factor group has been formed.

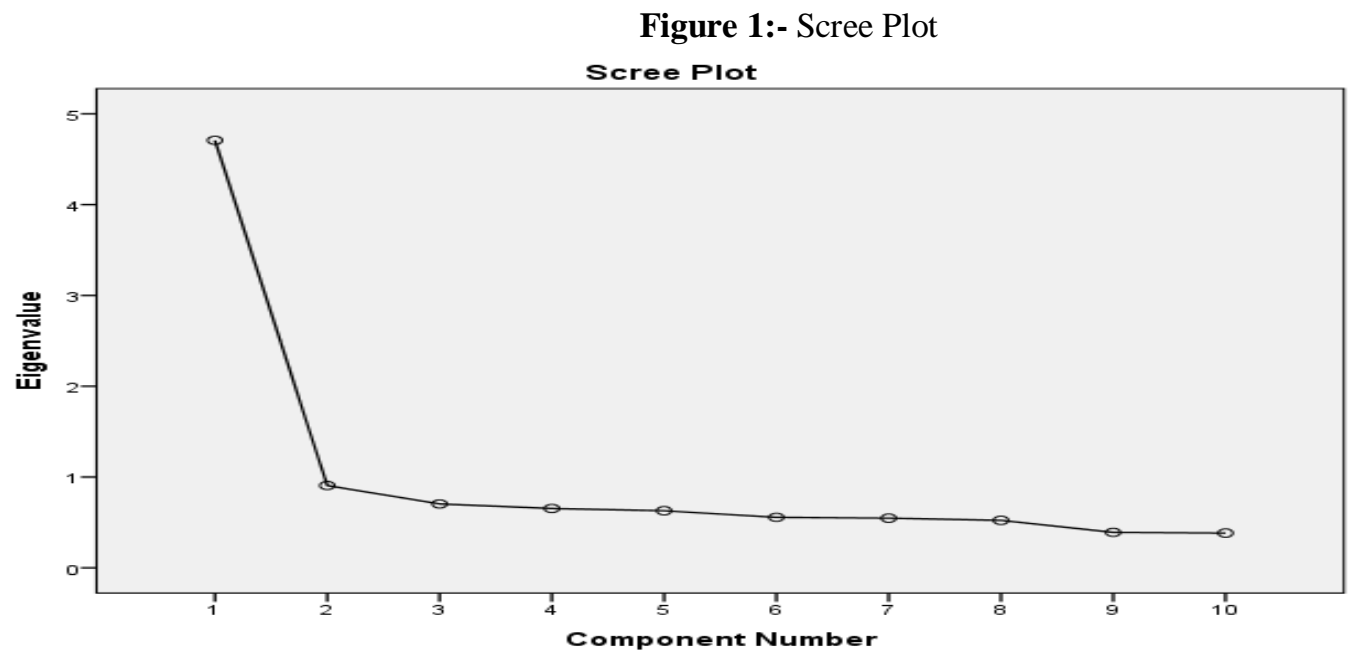

Table 3 shows the dominant factor that make up the company's performance-based human capital development process. Thus there are 10 dimensions which are the dominant factor forming the company's performance. The dominant factors are the company culture, job competency, company policy, System Operating Procedure, outsourcing, leadership, innovation, people development, fairness, and transparancy. The dimensions of the ten people development (0.738), leadership (0.722) and employee outsourcing (0.722) are keys success of this company.

Table 3:- Component Matrix ${ }^{\mathrm{a}}$

\begin{tabular}{|l|c|}
\hline \multirow{2}{*}{ Culture } & Component \\
\cline { 2 - 3 } & 1 \\
\hline Job_Comptency & .716 \\
\hline Policy & .629 \\
\hline System & .670 \\
\hline Offsourcing & .684 \\
\hline Leadership & .722 \\
\hline Innovation & .722 \\
\hline People_Development & .675 \\
\hline Fairness & .738 \\
\hline Transparancy & .684 \\
\hline \multicolumn{2}{|c|}{ a. 1 components extracted. } \\
\hline \multicolumn{2}{|c|}{} \\
\hline
\end{tabular}

\section{Conclusion and Recommendations:-}

This research concludes that there are 10 dimensions roomates forms of employee performance. The dimensions are company culture, job competency, company policy, SOP, offsourcing of employee, leadership, innovation, people development, fainess, and transparency. From the dimensions, people development, leadership, and offsourcing are three of the most dominant dimension. So that the company should develop sustimatically Reviews their employee based on their fields each. Leadership is also the most important to improve employee performance. So, it is suggested that leadearship based on bottom-up approach should be maintained in order to improve employee performance. In addition offsourcing employees give the company a fact the employee Constribute professional employee culture. It is because that the employees are experts in their fields. So that using offsourcing company should be maintained to color all employees in the company. 


\section{References:-}

1. Brahmasari \& Suprayetno. 2008. Pengaruh Motivasi Kerja, Kepemimpinan, dan Budaya Organisasi Terhadap Kepuasan Kerja serta Dampaknya pada Kinerja Perusahaan (Studi Kasus pada PT Pei Hai International Wiratama Indonesia).

2. David P. Lepak and Scott a. Snell. 1999. The Human Resource Achitecture: Toward a Theory of Human Capital Allocation and Development. Academic of Management Review, Vol 24 no, 1: 31-48.

3. Dolphina, Erlin. 2012. Pengaruh Motivasi, Kepemimpinan Dan Budaya Kerja Terhadap Kepuasan Kerja KaryawanSerta Dampaknya pada Kinerja Perusahaan. Seminar Nasional Teknologi Informasi \& Informasi Terapan. Vol. 2. No. 1.

4. Ferdinand, Augusty.2014. Metodologi Penelitian Manajemen. Edisi Kelima. Penerbit Badan Penerbit Universitas Diponegoro.

5. Herminingsih. 2011. Pengaruh Kepemimpinan Transformasional Terhadap Budaya Organisasi. Jurnal Fakultas Ekonomi: Optimal. Vol. 5. No. 1.

6. Hyun H. Son, 2010. Human Capital Development. Asian Development Bank Economics Working paper Series No 225.

7. KaplanR.S. and Northon D.P. 1996. The Balanced Score Card. Jakarta: Penerbit Erlangga.

8. Kuncoro, Mudrajad. 2009. Metode Riset Untuk Bisnis \& Ekonomi. Jakarta: Penerbit Erlangga.

9. Linawati, Suhaji. 2012. Pengaruh Motivasi, Kompetesi, Kepemimpinan Dan Lingkungan Kerja Terhadap Kinerja Karyawan (Studi Pada PT Herculon Carpet Semarang). Jurnal Kajian Akuntansi dan Bisnis. Vol. 1, No. 1.

10. Marimuthu, Maran, Layrence Arokiasamy, and Maimunah Ismail. 2009. Human Capital Development and Its Impact on Firm Performance: Evidence From Developmental Economics. The Journal of International Social Research, Vol 2/8 Summer 2009.

11. Munparidi. 2012. Pengaruh Kepemimpinan, Motivasi, Pelatihan Dan Lingkungan Kerja Terhadap Kinerja Karyawan Pada Perusahaan Daerah Air Minum Tirta Musi Kota Palembang. Jurnal Orasi Bisnis, Vol. 7, No. 1.

12. Nawawi, Ismail. 2013. Budaya Organisasi Kepemimpinan \& Kinerja. Jakarta: Penerbit Kencana.

13. Nurwati. 2012. Pengaruh Kepemimipinan Terhadap Budaya Organisasi, Komitmen Kerja, Perilaku Kerja dan Kinerja Pegawai (Studi pada Satuan Kerja Perangkat Daerah Propinsi Sulawesi Tenggara). Jurnal Aplikasi Manajemen. Vol. 10. No. 1.

14. Robert J. Thomas, Peter Cheese and james M Beton. 2003. Human Capital Develoment. Research Note. Issue One, November 2003

15. Robbins S.P. 1996. Organizational Behavior, Alih Bahasa Hadyana Pujoatmoko. Jakarta: PT Prenhaltindo,

16. Salain, Pradiva Putra. 2013. Pengaruh Kepemimpinan Terhadap Budaya Organisasi Inovasi dan Kinerja. Jurnal Aplikasi Manajemen. Vol. 26. No. 2.

17. Schein, Edgar H. 1992. Organizational Culture and Leadership. San Francisco, CA-Bass Publishers.

18. Sedarmayanti. 2001. Sumber Daya Manusia dan Produktivitas Kerja. Bandung: Mandar Maju.

19. Seminar, Ari Cahyo. 2015. Pengaruh Gaya Kepemimpinan dan Lingkungan Kerja Terhadap Kinerja (Studi Kasus pada Karyawan Bagian Produksi PT Essentra Indonesia, Sidoarjo). Jurnal Administrasi Bisnis. Vo. 26. No. 2.

20. Stephen, S.P. 2001. Organizations Behavior, Upper Saddle River, Prentice-Hall, Inc.

21. Subanidja, Steph (2015), The Forming Factors of Rural Bak Performance International Journal of Business and Management, Vol 3 Issue 8, August 2015.

22. Subanidja, Steph and Aiaz Rajasa (2016), Human Capital development Strategy for superior Organizational Performance, International Journal of Advanced Research, Vol 4, Issue 6, 257-260.

23. Suprayitno \& Dody Kristiawan. 2009. Pengaruh Motivasi Dan Lingkungan Kerja Terhadap Kinerja Karyawan Dengan Kepemimpinan Sebagai Variabel Moderating. Manajemen Sumber Daya Manusia. Vol. 3, No. 2. t

24. Sutrisno, Edy. 2010. Budaya Organisasi. Jakarta: Kencana.

25. Suwarto, F.X. 2014. Manajemen Kinerja. Yogyakarta: Cahaya Atma Pustaka.

26. Tika, Pandu. Moh. 2014. Budaya Organisasi dan Peningkatan Kinerja Perusahaan. Jakarta: Penerbit Bumi Aksara.

27. Widodo, Tri. 2010. Pengaruh Lingkungan Kerja, Budaya Organisasi, Kepemimpinan, Terhadap Kinerja (Studi pada pegawai kecamatan Sidoarjo kota Salatiga). Jurnal Ilmiah Among Makarti. Vol. 3, No. 5.

28. Yasin, Mahmudin. 2014. Organisasi Manajemen Leadership Studi Transformasi BUMN. Jakarta: Penerbit Expose (PT Mizan Publika).

29. Yulk, Gary A. 2013. Leadership In Organization Eighth Edition. United Stated of America. Prentice Hall. 